\title{
Pre-service Teachers' Beliefs Related to English as a Second Language and English as a Foreign Language: Where is the Difference?
}

\author{
Francis Bangou \\ Faculty of Education, University of Ottawa, 145 Jean-Jacques Lussier, Ottawa, ON, K1N 6N5, Canada \\ Email: fbangou@uottawa.ca; \\ Douglas Fleming \\ Faculty of Education, University of Ottawa, 145 Jean-Jacques Lussier, Ottawa, ON, K1N 6N5, Canada \\ Email: dfleming@uottawa.ca \\ Carol Ann Goff-Kfouri \\ Notre Dame University of Louaize, Zouk Mikael, P.O. Box 72, Lebanon \\ Email: ckfouri@ndu.edu.lb
}

\begin{abstract}
This article reports the findings of a qualitative case study examining the knowledge base held by English language teacher candidates enrolled in two university pre-service programs in Lebanon and Canada. Through an examination of blog postings and the data collected through semi-structured interviews, eight Canadian and eleven Lebanese respondents were polled while taking courses focusing on second language teaching methodology. Based on our findings, we argue that what teacher candidates know about their field of expertise is communal, contextually bounded and uniquely rooted in their experiences within and outside their pre-service programs. Moreover, the multitude of beliefs shared by these two groups of pre-service teachers demonstrate that there is indeed a universal knowledge base associated with the teaching of English as a Second Language (ESL) and English as a Foreign Language (EFL). However, we have also found significant differences between these fields based on specific and local contexts.
\end{abstract}

Index Terms -English, learners, knowledge, teacher, beliefs

\section{INTRODUCTION}

As second/foreign language teacher educators, our goal is in part to guide pre-service teachers in acquiring the knowledge base and savoir-faire that will enable them to successfully enter the classroom. We hope that such knowledge will constitute the foundation of their continuing growth as professionals. Within the field of second/foreign language education, what constitutes the core of such knowledge base has been the subject of a long lasting debate. According to Freeman (1989) second/foreign language teacher education has become fragmented. Too often, efforts focus on ancillary areas such as applied linguistics, methodology, or language acquisition while overlooking the core: teaching. He stated that "it is inaccurate and misleading to imply, as we do in most pre-service language teacher education that knowledge in methodology, applied linguistics, and language acquisition alone will necessarily enable or equip people to teach" (p.2). He identified two misconceptions that have often jeopardized the success of second/foreign language teacher education. The first misconception is that second/foreign language teacher education is based on the transmission of knowledge and skills in methodology and related areas. The second misconception is that transmission of knowledge will lead to effective practice. Such perspective implies that there is a fundamental universal knowledge associated with teaching English to Speakers of Other Languages (ESOL) and that acquiring such knowledge will prepare any language pre-service teacher to teach regardless of the context. In a later article, Freeman and Johnson (1998) argued that we should reconceptualize the knowledge base of second and foreign language teacher education so that we center on the teacher who does it (e.g. experiences, beliefs, background), the context in which it is done, and the pedagogy by which it is done. They claimed that our teacher education practices constitute our professional self-definition. What teachers know about teaching is largely socially constructed out of the experiences, beliefs and classrooms from which teachers have come. This paper is an attempt to contribute to this discussion. Based on Freeman and Johnson' claims, the present study was originally designed to analyse the knowledge that our students had acquired in our courses as a way to assess our practice as English as a Second Language (ESL) and English as a Foreign Language (EFL) teacher educators working respectively in Canada and Lebanon. More precisely, through an analysis of the teacher candidates' beliefs as articulated in their discourse we wanted to have a better understanding of the role that context played in the construction of such knowledge within our respective institutions and have a better 
comprehension of what constituted the core knowledge that defined us as ESOL teachers regardless of context (i.e. ESL, EFL and institutional). The research questions that guided this paper were:

1. Within the Canadian and Lebanese teacher education programs how did the pre-service teachers articulate their beliefs associated with: 1) the fields of ESL and EFL, 2) English Language Learners (ELLs) and 3) the act of teaching ESL and EFL?

2. Within the Canadian and Lebanese teacher education programs how did the teacher candidates articulate what contributed to the development of such beliefs?

3. What beliefs were shared by the Lebanese and Canadian pre-service teachers despite the contextual differences?

\section{PRE-SERVICE TeACHERS’ BeLIEFS}

According to Phipps and Borg (2009) "the study of teachers' beliefs has in the last 15 years emerged as a major area of enquiry in the field of language teaching" (p. 380). However, to our surprise we found little research on teachers' beliefs related to the field of ESL and EFL. As Pajares (1992) argues defining beliefs is not an easy task. They can refer to:

Attitudes, values, judgments, axioms, opinions, ideology, perceptions, conceptions, conceptual systems, personal theories, internal mental processes, action strategies, rules of practice, practical principles, perspectives, repertories of understanding, and social strategy, to name but a few that can be found in the literature (p. 309).

In this study we will refer to beliefs primarily as "complex and inter-related system of personal and professional knowledge that serves as implicit theories and cognitive maps for experiencing and responding to reality. Beliefs rely on cognitive and affective components and are often tacitly held" (Murphy, 2000, p.16). We chose this definition because we thought that it was more in line with Freeman \& Johnson's conceptualization of a knowledge base. Murphy's definition highlights the fact that beliefs are constructed through interactions within sociocultural contexts and provide a cognitive map that contributes to one's understanding of reality. They represent in fact our individual knowledge about our reality and as such teachers' beliefs are an important part of their knowledge base. A teacher's knowledge base is in fact the result of the interrelationships between prior beliefs and the knowledge acquired within specific institutional contexts. One of most controversial debate in the field is related to what constitutes core as opposed to peripheral beliefs (Pajares, 1992; Borg 2006). Although there is some disagreement as to what constitutes core beliefs, they are generally considered central to the teacher's practice, normative and stable. According to Murphy (2000) "understanding teachers' beliefs and how they are impacted on by a change in context or environment is a necessary first step in bringing about positive change in teaching and learning" (p. 14).

Stanosheck, Youngs and Youngs (2001) conducted a study related to the predictors of mainstream teachers' attitudes towards teaching ELLs. They created a model of predictors they believe are likely to explain teachers attitudes towards ELLs and they offered the following six categories of predictors they argued were suggested by "past EST-related research" (p. 99). (a) general educational experiences, (b) specific ESL training, (c) personal contact with diverse cultures, (d) prior contact with ESL students, (e) demographic characteristics, and (f) personality. The authors focused on gender. The research showed that women generally are more comfortable with interracial interaction and issues than men who tend to be more confused about racial issues (Ottavi, Poe-Davis, and Dings, 1994). They found that the teachers in their study were mainly neutral to slightly positive in their attitude toward teaching ELLs. The results show that mainstream teachers are most likely to have a positive attitude towards ELLs if they have had a foreign language or a multicultural education course, worked in the humanities, had ESL training, had lived or taught abroad, interacted with a culturally diverse population and are female.

Peacock (2001), did not focus on the predictors of mainstream teachers' beliefs but attempted to investigate changes in the beliefs about second language learning of 146 ESL pre-service teachers over a 3 year period of time. Peacock argued that there is a shortage of studies that investigate pre-service teachers' beliefs. According to this researcher, ESL teacher trainers should try to eliminate any detrimental beliefs before the pre-service teachers start to teach. The results show that most of the beliefs held by these respondents changed very little over three years. Most pre-service teachers still believed that learning a second language meant learning a lot of vocabulary words and grammar rules. It would be interesting to see if the teacher candidates in our study hold the same beliefs.

Mattheoudakis (2007) also attempted to track the evolution of pre-service second language teachers' beliefs during a three-year teacher education program. This researcher highlighted the fact that prior research tended to show that preservice teachers use their past experiences and beliefs to interpret the content of teacher education courses, they tend to use the information learned to reinforce rather than challenge prior beliefs (Powell, 1992; Tatto, 1998). However, later studies have challenged such findings (MacDonald.Badger \& White, 2001). Joram and Gabriele (1998) suggested that focusing on pre-service teachers' prior beliefs in instruction have an impact on the evolution of their beliefs. According to Cole and Knowles (1993) most pre-service teachers start their practicum with hopes, images, and expectations and during their teaching practice these images are shattered as they are exposed to school and classroom realities that do not match their expectation and previous experiences. Freeman and Richards (1996) have argued that beliefs strongly influence what pre-service teachers learn. Most of the studies dedicated to teachers' beliefs are based on a quantitative paradigm and according to the literature it seems that there is a need for more descriptive and explanatory research on second language pre-service teachers' beliefs. This multiple case study is an attempt to address this need. 


\section{MethodOLOGY}

Creswell (2007) argues that the design of a study should be related in part to the research topic and the way that the researcher prefers to address the research questions. As stated earlier this study focuses on pre-service teachers' subjective views on teaching English. We thought that emerging nature of this study was more in line with a qualitative perspective (Merriam, 2002) considering that we were trying to decipher the ways that our participants constructed their fields of ESL and EFL within specific institutional contexts. According to Anderson (1993) case studies are more focused on the how and why things happen and allow one to conduct an in depth analysis of the relationships between multiple elements within and across contexts. This is why we thought that a qualitative multiple case study was most appropriate to address our research questions.

\section{A. Contexts}

This multiple case study took place at two Faculties of Education: one in Canada and one in Lebanon. At the Canadian institution about 750 students attend the baccalaureate program in education every year in order to obtain their provincial certification to teach in public schools where English is the language of instruction at the primary and secondary levels. The program is focused on developing teacher candidates who are knowledgeable, competent and reflective professionals. It is therefore crucial for teacher candidates to be aware of how to concretely and critically connect theory with their own practice (Bangou \& Fleming, 2010). The full-time eight-month intensive program of study for this certification consists of 36 course credits and a mandatory ten week practicum (5 weeks in the fall and 5 weeks in the winter). The course which is the focus of this case was one of the optional classes that teacher candidates could attend. It was picked because it was the only course specifically in ESL of the program. The class met for three and a half hours once a week for 5 weeks. Four sections of the course were offered each year, two in the fall and two in the winter terms. Approximately 35 students enrolled in each. In this course pre-service teachers had the opportunity to study the current theories and practices of ESL teaching and learning. Some of the topics addressed were second language acquisition theory and research, the teaching and assessment of reading, writing, speaking and listening and their integration with other academic subjects, as well as strategies for integrating ESL students into the regular classroom. As teacher educators we wanted to give our students the opportunity to examine and practice fundamental concepts and approaches in a way that would allow them to determine how best to position themselves as ESL teachers. More specifically, at the end of the course, teacher candidates were expected to 1) demonstrate a basic understanding of some of the current issues, conceptual frameworks, methods and practices related to the teaching of ESL; 2) illustrate how these issues influence teaching options for diverse populations of students; and 3) determine their own orientation in terms of ESL teaching approaches, strategies and methods (Bangou \& Fleming, 2010). The text used in this class was The more than just surviving handbook: ESL for every classroom teacher (Law \& Ecks, 2000). It was a book specifically written for regular classroom teachers who wanted to attend to the needs of both the ELL and the mainstream students. The text was chosen because most of the pre-service teachers in the program had this profile. Moreover, this textbook was written by teachers and was full of practical and hands-on ideas which seem to always please teacher candidates. Each week we also had a PowerPoint presentation on diverse issues: ESL in Ontario; lesson and curriculum planning; ESL approaches and methodologies and culture, motivation and identity.

In Lebanon the official language is Arabic. Lebanon is unofficially tri-lingual in that businesses are run in French or English; though government papers are issued in Arabic, service in government offices is generally available in French or English. Private schools and universities rarely use Arabic as their language of instruction. The Lebanese institution of higher education at which this study was carried out uses English as its language of instruction. The Faculty of Humanities offers a M.A. and a B.A. in Education and a Teaching Diploma. Approximately sixty students were registered in the various education programs at the time of the study. Students register in a teaching diploma degree in order to obtain official certification to teach in both public and private schools where English is the language of instruction at both the primary and secondary levels. Students with a teaching diploma may also teach in schools where French is the first language of instruction and English is a second foreign language. Both the Bachelor of Education and the Teaching Diploma focus on forming teachers who are similar to candidates in Canada, knowledgeable of the subject matter, understanding of the student, and aware the classroom is not static. In Lebanon, candidates may choose the full-time option and in the case of the teaching diploma finish the 6 three credit courses and 1 mandatory practicum in one year and one summer, or they may choose to take courses part time. It is not rare that candidates work as supply teachers as they complete their degree. The course on which the study in Lebanon focused was the Teaching Practicum. This course was chosen because the Teaching Practicum is the capstone course which students take at the end of their course of studies and the content of this course was very similar to the one in Canada. It meets at the beginning of the semester for five three hour sessions before the students are sent to their teaching assignments. The pre-service teacher trainer observes the students on a regular basis during the 15 week semester and conducts class meetings to discuss the issues and the experiences of the students in the schools. The student must present a report at the end of the practicum and participate in whole class discussions of one of their classes on videotape. Students in this class had already taken the methodology courses; pre-service teachers had the opportunity to study the current theories of teaching in general and in particular those used in an EFL context. Subjects covered in the class are similar to those in the Canadian syllabus: teaching of reading, writing, speaking, listening; and the integration of the English language in the teaching of 
other academic subjects such as the sciences and mathematics. The professor of the practicum course focuses on the importance of adopting methodology in teaching. By that we mean that the teacher is encouraged to make the classroom learning environment as learner centered as possible and thus the need for an understanding of learning outcomes and how to incorporate them into the teaching objectives. At the end of the course, the students were expected to 1) demonstrate understanding of current educational theory including principles of teaching EFL; 2) present microteaching sessions in which these theories were evident; and 3) show proof of having developed their philosophy of education. There are no textbooks used in this class. Students refer to all the textbooks they have used during their 6 courses.

\section{B. Participants}

Although qualitative case studies usually deal with small samples of participants, their trustworthiness are ensured by the use of multiple sources of evidences, cross-case examination and within-case examination in parallel with the review of the literature (Yin, 2009).

In Canada, since one of the researchers was also the instructor of the class for ethical reasons we had to ask our research assistant to recruit the participants. Eight pre-service teachers accepted to participate in the research. The participants were representative of the student population in the B.Ed. program. The age range of these teacher candidates was between 23-40 years. Although most of these teacher candidates had no prior teaching experience a significant number had taught English abroad or in Canada.

In Lebanon, the instructor of the class was not involved in the study. We invited the students in the Practicum class to participate in the study at the fifth week of the semester. A total of 11 students signed the consent form. The age range of the teacher candidates was between 21-30 years. The students are representative of the population of pre-service teachers at the university. They all come from diverse backgrounds; parents are Lebanese who had emigrated to Africa, Europe and the Gulf states and then returned to Lebanon so that their children could continue their university studies. The students consider themselves to be multi-cultural. All of the participants had teaching experience even though they had not yet received their degrees.

\section{Data Collection}

In this multiple case study, two data collection strategies were used both in Canada and Lebanon; they were 1) blog postings and 2) semi-structured interviews. We thought that the data would be richer if we could capture participants' beliefs and experiences as they were expressed naturally through their interactions with their peers. In Canada, as part of the course requirements teachers candidates had to contribute to a blog related to the content of the course. We realized that the blog provided the teacher candidates with the space to react both collectively and individually to the course material and express a range of spontaneous emotions, and opinions. This is why we decided to use the blog postings as data. The pre-service teachers were aware that their participation in the study had no impact on their grade for the course. In Lebanon, the blog postings were not part of the requirements of the course. However, in order to conduct the study in a similar fashion in both research settings Lebanese participants were asked to contribute to a blog around questions related to their general experience as pre-service teachers in the course and in the classrooms.

In both Canada and Lebanon each participant was interviewed once. The objective of these semi-structured interviews was to allow participants to describe their experiences within the courses and the programs in their own words without controlling or predicting their behaviour. Moreover, the interviews enabled us also to elaborate on points we thought were interesting in the blog postings

\section{Data Analysis}

Both in Canada and Lebanon, we carefully went through the interview transcripts and the blog entries and an initial list of codes was created from the research questions and our theoretical framework (e.g. prior beliefs, teaching, course material, etc.). Afterward, we conducted a content analysis and highlighted the emerging themes (e.g. influence of past experience, frustration, teaching, etc.). This procedure was repeated across participants and across contexts to identify the shared themes and patterns. Through this analysis we were able to highlight the ways the research participants constructed their knowledge within the program as well as their beliefs related to 1) the field of ESL/EFL 2) ELLs and 2) the act of teaching ESL/EFL.

\section{RESULTS}

\section{A. The Fields of English as a Second and English as a Foreign Language}

Both Canadian and Lebanese participants agreed that the course contributed to their knowledge related to ESL. For example a Canadian teacher candidate said: "The course helped me think about what my convictions are about language and learning in the contacts to ELL." Both courses provided an arena where pre-service teachers deconstructed and reconstructed their field of expertise. For instance, most of the Canadian participants struggled during the interview to provide a clear description of what they believed the field of ESL referred to. Such statements were not unusual: "I don't know if I'm right on that definition, but that's the way I am distinguishing it, I guess in my mind." For some "ESL should cover anybody who is in need of help for the language." Others where a little bit more specific: 
"For me, ESL is teaching English as second language, which means I think a bit of teaching anybody, child or adult, who must learn another language in order to survive in order to succeed, in order to function." This pre-service teacher believed that the field of ESL addressed specific instrumental needs and it seems that people who wanted to learn the language just for pleasure were not included. It is true that a majority of the Canadian participants made a clear distinction between ESL and EFL: "Well, I distinguish between ESL here and ESL in other countries in a sense, really it's more EFL, which means English as a foreign language because that's not an environment where they are going to be using English." It is true that in the course we did focus on contexts where English was the predominant language of communication outside of the classroom, mostly because it was the primary context where the teacher candidates were going to work. Moreover, it is true that most of the course material was dedicated to the challenges faced by ELLs and the ways that teachers could attend to their needs. It might be why for a majority of participants believed that ESL referred mainly to contexts where learners had no choice but to learn the language if they wanted to succeed or fully participate in a host society: "I can consider someone learning a second language when there is an urgency. They need to work on that language. They need to educate themselves in that language."

Interestingly in Lebanon they made the same distinctions between ESL and EFL and it had an impact on the way that they referred to their field of expertise. As was stated before, Arabic is the official language and for that reason English would be considered a Foreign language. However, as stated before it is not uncommon to hear people conversing in English or French, or Armenian in places of business; newspapers are published in Arabic and English, French and Armenian, and schools choose one of the languages other than Arabic to use as its language of instruction. It must be said that there is a cultural element to this situation as a foreign language is seen as a tool to acquire access to better employment possibilities in the future. Though Lebanese are not obliged to speak a foreign language in the work place, in general they do and English is quickly becoming the second language of choice for most Lebanese citizens who consider themselves as forward thinking. Because of the sociocultural status of English in Lebanon, most people feel that they have no choice but to learn the language to be successful. It was definitely the case of the Lebanese participants since in the institution where the research took place English was both the language taught and the language of instruction. The Lebanese pre-service teachers in the study were all aware of the specificities of their situation and that the courses they had taken were conditioning them to the particularities of ESL "I am learning that a lot of my students are spending lots of time in an English language atmosphere..." Their challenges seemed to be very similar to the Canadian participants: "But even though they [language learners] are exposed to the language, there are hurdles that they must surmount. They don't all use correct expression." This is why most of Lebanese participants referred to their field of expertise as ESL rather than EFL.

To our surprise, a number of Canadian participants did compare the field of ESL to the field of teaching students with exceptionalities: "Like I think LD [learning disability] like ESL is like, giving people the right tools for how they learn or like, the tools like to get to the point where everyone else is." As professors, we never made such comparison; however, we did put an emphasis on the fact that it was important for ESL teachers to provide the right accommodations to the ELLs. It might be why some pre-service teachers made the connection between the two fields. The Lebanese pre-service teachers did not make such comparison, however they were also aware that as English teachers they will have to provide the right accommodations to their students: "I now know that I must possess a rich vocabulary. I need to slow my pace, use understandable vocabulary, but at the same time not speaking in a wrong way so that students could understand."

Although, the teacher candidates conceptualized the field of ESL and EFL in numerous ways, both the Canadian and Lebanese pre-service teachers believed that it was necessary for any teacher to develop a knowledge base related to ESL/EFL and this is partly why some of them decided to enrol in the course. For instance a Canadian participant said during an interview: "I think what drew me to the course most was that I fully acknowledge that ESL and ELL that is something that's asset for any teacher." A Lebanese pre-service teacher declared: "ESL teachers are able to understand the students' needs to have definitions and to simplify the terms of a Math lesson. We have to help the content teachers." Both Canadian and Lebanese participants felt the urgency to develop their knowledge base related to teaching English to better attend to the needs of their student population. As an elective the Canadian course was only offered for five weeks and most pre-service teachers did not understand why it was not a requirement and was not offered as a full course. The Lebanese pre-service teachers felt that their training had provided them with more than other teacher trainees.

\section{B. English Language Learners}

In the Canadian institution the Ontario curriculum (2007) was used to define an ELL. In this document ELLs were:

Students in provincially funded English language schools whose first language is a language other than English, or is a variety of English that is significantly different from the variety used in instruction in Ontario's schools, and who may require focused educational support to assist them in attaining proficiency in English (p.8).

Such student population included international students, immigrants, refugees and Canadian born for whom English was not a first language (francophone or autochthones).

This definition did challenge Canadian pre-service teachers' prior beliefs related to ELLs and at the end of the course most of them were still in the process of integrating this new definition: 
English language learners means a different language beings the first language and I do not know. I have to think so one second...I guess what's important for me like, that would be a student coming with the purpose of using or learning English as a means of communicating in the current society.

As we can see this participant struggled with the notion of first and second language and goes back to what seems to be a fairly traditional definition of a language learner - someone who is learning a second language as means to communicate in society. It is true that until this class Canadian pre-service teachers were used to the term ESL learners. For a majority of them it was even the first time that they heard the term ELL, and they were still trying to make sense of it. They knew that the term ELL was preferred but it was difficult for them to conceptualize it:

This is the second language, so English as a second language I think that what it sounds for. So you are learning English to be a second language, but I think the professor mentioned that, uhm, it's we can't, it's not really appropriate to use the term ESL, especially, you know for people in Ontario, cause a lot of kids, already speak, you know a second language.

For this pre-service teacher ELL seems to be just a politically correct translation of ESL. Most of the Canadian preservice teachers struggled with integrating this new term into their discourse. For instance, when asked specifically to tell us what ELL meant to her a teacher candidate responded: "Well for me, I mean ESL or ELL or someone who is learning English, is anyboby whose language, whose first language isn't English and who struggles with it." As we can see this participant started her response automatically with ESL then she used the preferred term ELL and then she provided a more descriptive reference to the concept "someone who is learning English" to be sure that she covered all her basis and that we knew what she was referring to.

Some of the Canadian participants made a clear distinction between ESL students and ELL:

I think that my last students are ESL students. I don't think they are ELL students, because they are learning it as their second language, but they are speaking at home and a community and everywhere else, then I think it's their second language as an addition to their first language, but ELL students are maybe learning it as, like, we are not keeping, we are not worried about keeping it is just kind of that. We are not worried about them learning both languages together. We are worried them to learn English.

It seems that for this pre-service teachers ESL students are more in an additive bilingualism situation whereas ELLs are more in a subtractive bilingualism context. We do not know what trigger such association but in the mind of this participant this is how it made sense to her.

Despite the definition that was provided to them most Canadian participants used their own criteria to make sense of such concept. Some teacher candidates believed that ELLs referred to anybody who learns English and it could be their first or second language:

An English Language learner it is a person who is learning English language and I think it could range from an invent who, you know well, on the cognitive processes has begun and started like to recognize, you know what people talk, their words, you know, the baby starts to say, like, a-a, it makes sound you know, I think that's they started t learn language then.

As we can see for this pre-service teacher babies learning their first language could be considered ELLs. Connected to that idea is the belief that learning a language is a life long process for both first and second languages:

Everyday you can learn a new word...so I think that you are always an English language learner...I think that even when you are seventy, you are still learning language. So that's kind of what I think ELLs are. People go learning English, which is everyboby, and it never ends.

Others were more specific, to them ELLs refer mainly to learners for whom English is not a first language: "I guess somebody who either, did not learn English as their first language or even if they did learn it along with the another language it is not a primary language that they use...somebody who basically struggles with English" The notion of struggle was often associated with ELLs: "Having an ESL student. I don't have any that I teach, but just from the course and having spoken to that professor who went through the process and his student life. It's really something; it's really difficult for them." The first author of this article was himself an ELL and he did use his experience to illustrate some of the points discussed in the course. It seems that what was the most important was not what was taught but what had the most impact on them. When providing a definition in the class most Canadian teacher candidates were surprised by the diversity of the ELLs population. It might be why a majority of participants referred to such notion when talking about ELLs: "There can be a range of ELL students."

Within the Lebanese program they did not refer to the curriculum to define ELL and teacher candidates did not have the same struggles to grapple with the distinction between ESL learners and ELL. To them, anybody for whom English is not the mother tongue would be an ELL which was the definition shared by most Canadian participants prior to the program. However, most of the Lebanese participants recognized that ELL "have needs and we must work upon them." Very interestingly none of the Lebanese pre-service teachers indicated the types of needs the ELL had in their responses. It might be because as ELL themselves they assumed that their audience knew what these needs were. Moreover, the Lebanese student teachers were teaching English in an environment where English was perceived by many as a means to travel and work in countries such as Canada.

C. Teaching 
At the end of the program most of the Canadian and Lebanese pre-service teachers believed that teaching English was an overwhelming task. For instance a Canadian pre-service teacher declared during an interview: "It just felt overwhelming in that there are so many strategies and so many resources that you want to use. That's it, I found it overwhelming. " It might be why a majority of the Canadian and Lebanese participants emphasised that it was important for teachers to be well prepared: for instance a Lebanese participant said: "If I hadn't gone through every single class on my contract sheet, I wouldn't be able to stand up and perform in front of a class." In fact, throughout the program the pre-service teachers realized that teaching English was not just about teaching the language. For instance, a Canadian teacher candidate declared: "For me, I think it would be very intimidating at first, to have an ELL in my classroom because it's not just a language thing, it's often cultural as well." Both Lebanese and Canadian pre-service teachers not only cited theoretical knowledge of teaching ESL/EFL but general educational theory. For instance, a Lebanese pre-service teacher declared on the blog: "Bloom's Taxonomy is always present in my lesson plans. I can't begin a lesson with a synthesis activity if the knowledge aspect has not been covered." In this example, this participant has integrated into his discourse a theory that was introduced in the course. It is something that was recurrent throughout the data. Both Canadian and Lebanese teacher's beliefs related to teaching were intrinsically connected to their experiences in the course and the material that was covered: "I feel that I have to identify the domain of the educational activity I am carrying out to see if it is cognitive, affective or psychomotor."

However, their experiences outside of the course also had an impact on their beliefs related to teaching. For instance a Lebanese participant declared

Öne time when I entered class and started my lesson there was a student sleeping on her desk, I came next to her and asked her what is wrong. She said she has a headache. I asked her to go out of the class, wash her face, take medicine if necessary and come back to class. She stayed around five minutes outside the class but when she came back she was much better and she was involved in the class activities and participation. It is very important as teachers to notice the students' needs and work upon them.

Here, in order to introduce what she believes is important when teaching this pre-service teacher referred to something that happened to her in the classroom. Through this story this teacher candidate both illustrated and justified her point of view. Generally when expressing their beliefs about teaching, teacher candidates usually referred to their experiences in the schools. For both groups of teacher candidates the practical seemed to more important as a Lebanese participant reported: "theories alone are like living in a dream." It is true, that both groups of pre-service teachers came to the program with prior beliefs related to teaching English that were based on their experiences as language learners and/or instructors and a lot of teachers candidates struggled with the course content when it contradicted what they learned in other classes: "I was surprised to read this. In my Kindergarten class we learned that it is in fact very important" and as language learners: "To me it does not make sense. Everyone should learn the alphabet... that's how we all start learning."

Other struggles were also expressed. As native speakers of English, most Canadian pre-service teachers declared that they had never studied the grammar of English and a number of them believed that it could be a handicap: "I do not know the exact rules and I wished that I knew." Teaching grammar seemed to be one of the recurring themes in the Canadian interviews and blogs entries.

However, the Lebanese pre-service teachers were not so concerned with teaching grammar. It might be because as non-native speakers of English they studied the grammar and they had more confidence in their ability to teach it. However, they were more worried about their inability to provide their learners with enough exposure to the language. Indeed, the term "exposure" was repeated many times by the participants in the Lebanese study. It is so important for students to be exposed to the English language by way of classroom discussions, reading and participating in conversation with others so that the students being taught ESL could advance. Teachers who are primarily ESL teachers must do lots of practical and teaching in the schools." Here we can see how both groups of teachers candidates' beliefs associated to their ability to teach were intrinsically connected to their background and sociocultural contexts were they taught. As native speakers working in an ESL setting the Canadian participants doubted about their ability to teach the grammar whereas a non native speakers of English in an EFL context the Lebanese teachers were more concerned with their ability to provide their students with enough exposure to the language.

As we can see pre-service teachers knowledge base related to teaching ESL/EFL was constructed throughout their experiences in their practicum, their classes and in the course. The program constituted a site of deconstruction and reconstruction where many prior beliefs were transformed or reinforced.

\section{DISCUSSION}

In both the blog entries and interviews both groups of teacher lay an enormous emphasis on $I$. Most of the respondents in both Lebanon and Canada provided their opinion regarding teaching ESOL. In response to the first question both groups of teacher candidates believed that the field of ESL/EFL were important and contributed to the greater good and that it was crucial for any teacher to develop a knowledge base associated with teaching English to second language learners and emphasized the importance given to learning English as a means of communication for the student. Both groups made a distinction between ESL and EFL contexts. The major criterion used by both groups of participants to distinguish the two contexts was the fact that to them in an ESL context usually the ELLs had no choice 
but to learn the language to be successful. This is why the totality of Lebanese referred to their context as ESL instead of EFL. Here it is interesting to notice how this notion of urgency to learn to language was understood according to their socio-cultural contexts. The Canadian pre-service teachers referred primarily to the full participation of newcomers in the host society, whereas the Lebanese participants referred primarily to their own participation within a society where English was steadily becoming the language associated with success. The socio-cultural context also had an impact on teachers beliefs associated with ELLs. Although both groups of participants referred to different population of students they both agreed that ELLs had specific needs that needed to be addressed in particular ways. Indeed, the Canadian participants referred primarily to learners who were struggling with the variety of English spoken in the Canadian schools whereas the Lebanese teachers referred primarily to anybody for whom English was not a first language. Interestingly it seems that prior to the teacher education program it was the way a majority of the Canadian participants defined an ELL and this is partly why at the end of the course a majority of them were still reconstructing their knowledge associated to ELLs. Both groups of participants were also still constructing their knowledge associated with teaching English. However both groups believed that teaching English was a challenge and teachers needed to be well prepared to do so. Once again the sociocultural contexts had an impact on the type of challenges the pre-service teachers associated to the act of teaching English. Indeed, on one side as native speakers of English working in a social context where English was the predominant language the Canadian pre-service teachers were more concerned with their ability to teach the grammar. On the other side, as non native speakers of English working in a social context was English was not the predominant language the Lebanese teachers were more concerned with their ability to provide their students with enough exposure to the target language.

In response to the second question, the data show that it is important to place the teacher education programs within larger socio-cultural contexts because they do have an impact on the way that the pre-service teachers are going to appropriate the material that is presented to them. The data show that the information provided within the programs had an impact pre-service teachers' beliefs associated with teaching English. However, this information was interpreted, transformed and appropriated according to the pre-service teachers' background and experiences in the classrooms as teachers or learners. It appears that the pre-service teachers had the most difficulty when the information provided in the programs contradicted previous beliefs acquired through experiences in the classroom. It seems that the pre-service teachers referred primarily to their personal experiences in the classroom to validate a theory, illustrate a point challenge the content of the course or deconstruct and reconstruct their prior beliefs. These results echo previous studies on the subject (Pajares, 1992; Richardson, 1996; Freeman and Richards, 1996).

In response to the third question, the data show that the teacher candidates did share some beliefs regarding their field of expertise. For instance, both groups of participants believed that teaching English was challenging and that ELLs had specific needs. However, as said earlier the data also show that these overarching beliefs took on different meanings for Canadian and Lebanese teachers or for individual participants. Phipps \& Borg (2009) argue that when talking about relationship between beliefs and practice it is important to make the distinction between different types of beliefs. Based on the results we would argue that when talking about pre-service teachers' knowledge it is important to distinguish between communal and personal beliefs. Communal beliefs would constitute part of our international, national and regional shared knowledge and contribute to the development of communities of experts. They usually refer to granted principles, ideas, definitions and concept associated with teaching a language. For instance, believing that ELLs had specific needs would be an example of internal communal beliefs. Whereas, believing that an ELL's main need is to master the variety of English spoken in the schools of a specific province would be an example of provincial communal beliefs. Personal beliefs would constitute part of our individual knowledge and contribute to our unique understanding of our field of expertise and concepts. These types of beliefs are often associated to new concepts that are sources of struggles and they usually do not match with communal beliefs. For instance, believing that ESL learners and ELLs are different because ESL learners contrary to ELLs are more in an additive bilingualism context would be a personal belief Depending of the context and community a communal belief could become a personal belief and vice versa. However, both communal and individual beliefs are rooted in sociocultural contexts and experiences, are subject to change and contribute to pre-service teachers' knowledge associated to ESL/EFL teaching.

\section{CONCLUSION}

This study did echo previous research on second language pre-service teachers' knowledge base. Indeed, through the analysis of their beliefs we were able to show that what teacher candidates' know about their field of expertise is contextually bounded and rooted in their experiences within and outside the teacher education programs. It also appeared that their beliefs affected the way that they appropriated the information that was provided within the programs.

Moreover, through this study of we were able to show that the teacher candidates' knowledge associated with teaching English was both communal and unique. If a universal knowledge exists associated with teaching ESL or EFL, it is not solely based on methodologies and theories but also on the struggles, questions, and issues that are unique to our profession and characterizes us as a community of learners and practitioners regionally, nationally and internationally. We believe that these findings illustrate the complexity of what constitute an ESL/EFL teacher's knowledge base and contribute to the discussion on this topic. However, more research needs to be conducted. For 
instance, we need more studies on communal and personal beliefs and their interconnections and the way that we can effectively foster both within our teacher education programs.

\section{REFERENCES}

[1] Anderson, G. (1993). Fundamentals of educational research. London: Falmer Press

[2] Anderson, R.D. (1995). Curriculum reform: Dilemmas and promise. Phi Delta. Kappan, 77 (1), 33-36

[3] Borg, S. (2006). Teacher cognition and language education: Research and practice. London: Continuum

[4] Cole, A. L. \& Knowles, J.G. (1993). Shattered images: Understanding expectations and realities of field experiences. Teaching and Teacher Education, 9(5/6), 457-471.

[5] Creswell, J. W. (2007). Qualitative inquiry and research design: Choosing among the five approaches (2 ${ }^{\text {nd }}$ edition). Thousand Oaks, CA: Sage Publications, Inc.

[6] De Guerrero, M. \& Villamil O. (2000). Exploring ESL teachers' roles through metaphor analysis. TESOL Quarterly, (34)2, 341-351.

[7] Edge, J. and Richards, K. (1998). Why best practice is not good enough. TESOL Quarterly,32(3), 569- 576.

[8] Freeman, S., A., (1941). What constitute a well-trained modern language teacher? Modern Language Journal, 25, 293-305.

[9] Freeman, D. (1989). Teacher training development and decision making: A model of teaching and related strategies for language teacher education. TESOL Quarterly, 23(1), 27-44.

[10] Freeman, D, \& Johnson, K. (1998). Reconceptualizing the knowledge-base of language teacher education. TESOL Quarterly, 32(3), 397-416.

[11] Freeman, D. and Richards, J. (1993). Conceptions of teaching and the education of second language teachers. TESOL Quarterly, 27(2) 193- 216

[12] Freeman, D. and Richards J. (1996). A look at uncritical stories. In Freeman, D. and Richards, J. (Eds.) Teacher Learning in Language Teaching. CUP, Cambridge, p1-6.

[13] Joram, E., \& Gabriele, A. J. (1998). Preservice teachers' prior beliefs: transforming obstacles into opportunities. Teaching and Teacher Education, 14(2), 175-191

[14] Lafayette, R.C. (1995). Subject matter content: What every foreign language teacher needs to know. In Guntermann, G. (Ed.). Developing Language Teachers for a Changing World. Chicago: National Textbook Company.

[15] Little, J.W. (1993). Teachers' professional development in a climate of educational reform. Educational Evaluation and Policy Analysis, 15(2), 129-151

[16] MacDonald, M., Badger, R., \& White, G. (2001) Changing values: What use are theories of language learning and teaching? Teaching and Teacher Education, 17, 949-963.

[17] Mattheoudakis, M.(2007). Tracking changes in pre-service EFL teacher beliefs in Greece: A longitudinal study. Teaching and Teacher Education, 23, 1272-1288.

[18] Merriam, S.B. (Ed.) (2002). Qualitative research in practice: Examples for discussion and analysis. San Francisco: Jossey-Bass.

[19] Murphy, E. (2000). Strangers in a strange land: Teachers' beliefs about teaching and learning French as a second or foreign language in online learning environments. Retrieved from http://www.nald.ca/Fulltext/stranger/cover.htm

[20] Ontario Ministry of Education (2007). English Language Learners ESL and ELD program Programs Services: Policies and Procedures for Ontario Elementary and Secondary Schools, Kindergarten to Grade 12. Retrieved on February $23^{\text {rd }} 2010$ from http://www.edu.gov.on.ca/eng/document/esleldprograms/esleldprograms.pdf

[21] Ottavi, T.M., Pope-Davis, D.B. \& Dings, J.G. (1994). Relationship between white racial identity attitudes and self reported multicultural counselling competencies. Journal of Counseling Psychology, (41), 149-154.

[22] Pajares, M. F. (1992). Teachers' beliefs and educational research: Cleaning up a messy construct. Review of Educational Research, (62)3, 307-332

[23] Peacock, M. (2001). Pre-service teachers' beliefs abut second language learning: A longitudinal study. System, 29, 177-195.

[24] Phipps, S. \& borg, S. (2009). Exploring tensions between teachers' grammar teaching beliefs and practices. System, 37, 380390.

[25] Powell, R. R. (1992). The influence of prior experiences on pedagogical constructs of traditional and non-traditional preservice teachers. Teaching and Teacher Education, 8(3), 225-238.

[26] Richards, J. (1998). Beyond training. Cambridge, UK: Cambridge University Press

[27] Richardson, V. (1996). The role of attitudes and bleifs in learning to teach. In: Sikula, J. Butery, T.J., Guyton, E. (Eds.) Handbook of Research on Teacher Education, $2^{\text {nd }}$ Edition. Macmillan, New York, 102-119.

[28] Stanosheck Youngs, C., Youngs, G. (2001). Predictors of mainstream teachers' attitudes towards ESL students. TESOL Quarterly. (35)1, 97-120

[29] Tatto, M. T. (1998). The influence of teacher education on teachers' beliefs about purposes of education, roles and practice. Journal of Teacher Education, 49(1), 66-77.

[30] Yin, R. K. (2009). Case Study Research: Design and Method. (4th ed.). California: Sage Publication.

Francis Bangou earned his Ph.D. in Second Language Education from the Ohio State University in 2003. He is currently an Assistant Professor at the University of Ottawa. He has published in journals such as ALSIC, The International Journal of Intercultural Relations, and E-Learning and Digital Media. His research focuses on the integration of technology into second language classrooms, second language pre-service teachers' knowledge-base development, technological literacies, and teachers' appropriation of unfamiliar work environments. Dr. Bangou is a member of the American Educational Research Association, and the Canadian Association of Applied Linguistics. 
Douglas Fleming earned his Ph.D. in Second Language Education at the University of British Columbia. He has been an Assistant Professor at the University of Ottawa since 2007. He has published in such journals as the Canadian Journal of Education, TESL Canada Journal, and Citizenship Education Research. His current research focuses on multiple literacies, English as a Second Language and citizenship. Dr. Fleming worked as a public school teacher for 20 years before entering academia.

Carol Ann Goff-Kfouri presently lives in Lebanon, but was born in Canada and raised in the USA. She holds degrees from the US and France and earned her $\mathrm{PhD}$ in Education from USEK in Lebanon. Her area of emphasis is teacher training, especially at the classroom management level. After chairing the department of English, Translation and Education at Notre Dame UniversityLouaize in Beirut for 6 years, she now holds the position of Dean of the Faculty of Humanities at the same university. Dr. GoffKfouri has published articles on teacher training, classroom management and teaching methodology for translation instructors in regional and international publications and she is often called upon to speak on teaching methodology at conferences. 